\section{FaRUARY METIIICS}

Feb. 4. Process Control of Protein Purification. London. Info: $T . J$. Bonham Carter, Hon. Secretary, Society of Chemical Industry, 14/15 Belgrave Square, London SW1X 8PS, U.K.

Feb. 5. Applications of Fluorescence Techniques to Biological Problems. Urbana, IL. Info: Janet Glaser, Biotechnology Center, University of Illinois, 901 South Mathews, Urbana, IL 61801

Feb. 9-15. UCLA Symposium on Proteases in Biological Control and Biotechnology. Park City, UT. Info: UCLA Symposia, 103 Molecular Biology Institute, University of California, Los Angeles, CA 90024

\section{Mrac nismies}

March 3-4. Biotechnology \& Medical Asia, 1986. Columbus, OH. Info: Paul Ki, Editor-in-Chief, Asian Medical \& Biotechnology News, 255 West, Tenth Ave., Columbus, OH 43201

March 3-6. Biological Regulation of Cell Proliferation. Milan, Italy. Info: Ares-Serono Symposia, Via Ravenna, 8, 00161 Rome, Italy

March 10-14. 37th Pittsburgh Conference and Exposition on Analytical Chemistry and Applied Spectroscopy. Atlantic City, NJ. Info: The Pittsburgh Conference, 437 Donald Road, Dept. FP, Pittsburgh, PA 15235

March 23-28. 86th Annual Meeting of the American Society for Microbiology. Washington, D.C. Info: Richard A. Bray, Meetings Dept., ASM, 1913 I St., NW, Washington, D.C. 20006

March 25. Toxicology Testing without Animals. London. Info: See for Feb. 4.

March 25-26. Process Possibilities for Plant and Animal Cell Cultures. Manchester, U.K. Info: C. Webb, Dept. of Chemical Engineering, U.M.I.S.T., P.O. Box 88, Sackville St., Manchester M6O 1QD, U.K.

March 25-27. BCC Conference on Biotechnology. Stamford, CT. Info: Business Communications Co., 9 Via- duct Road, Stamford, CT 06907

\section{counass}

Feb. 26-28. ATCC Course on Freezing \& Quality Control: Cell Cultures \& Hybridomas. Rockville, MD. Info: See for meeting on April 28-29.

March 3-7. Hybridomas in Biotechnology and Medicine. Boston, MA. Info: Harvard Medical School, Dept. of Continuing Education, Boston, MA 02115

March 17-21. ATCC Course on Recombinant DNA. Rockville, MD. Info: See for meeting on April 28-29.

April 8. Biotechnology and the Agri Industries. Part 2-Plant Biotechnology. Edinburgh, Scotland. Info: Keith James, Dept. of Surgery, University of Edinburgh Medical School, Teviot Place, Edinburgh, EH8 9AG, Scotland

\section{JXedme chanes}

Invitron Corp. (St. Louis, MO) appointed William B. Beedle vice president for finance and chief financial officer.

BioTechnica International (Cambridge, MA) named Richard L. Dalton vice president for affiliates and contracts, and appointed Michael A. Santoro general council.

T Cell Sciences (Cambridge, MA) appointed David L. Corbet director of commercial development.

The New Jersey Center for Advanced Biotechnology and Medicine (Piscataway, NJ) named Aaron J. Shatkin director, effective this summer. Shatkin is currently with the Roche Institute of Molecular Biology.

Chembiomed Ltd. (Edmonton, $\mathrm{Al}$ berta, Canada) appointed E. J. Cuyler senior vice president of operations.

\section{AGRI-BIOTECHNOLOGY EXECUTIVE SEARCH}

KINCANNON \& REED provides executive search consulting to agri-biotechnology management. We represent biotechnology organizations in successfully identifying, evaluating, and attracting the superior research and commercial talent necessary to achieve their objectives.

Because our emphasis is in agribusiness, we are better able to counsel our clients on their key management needs. With our well developed sources in agribusiness and the agri-scientific community, we provide a comprehensive overview of the executive market.

Working efficiently, we bring to every search an expertise sharpened by daily practice. Our perspective, diligence and objectivity, as well as close communication with clients, are key to successful searches.

If your organization has or anticipates key management needs, please write or call.

\section{KINCANNON \& REED \\ 200 South Hanley Road}

St. Louis, Missouri 63105 USA

(314) $727-1960$

Write in No. 87 on Reader Service Card 